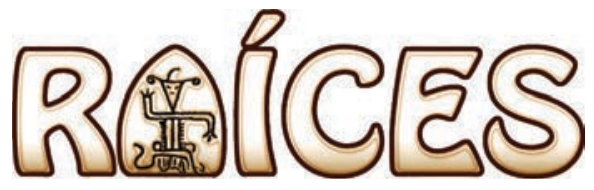

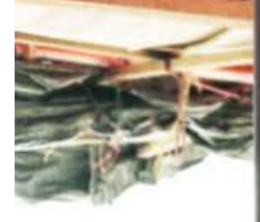

REALIDADES

URBANAS Y RURALES

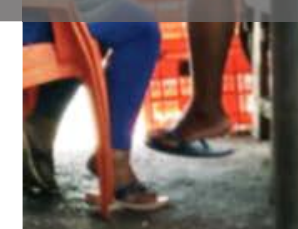

ini-
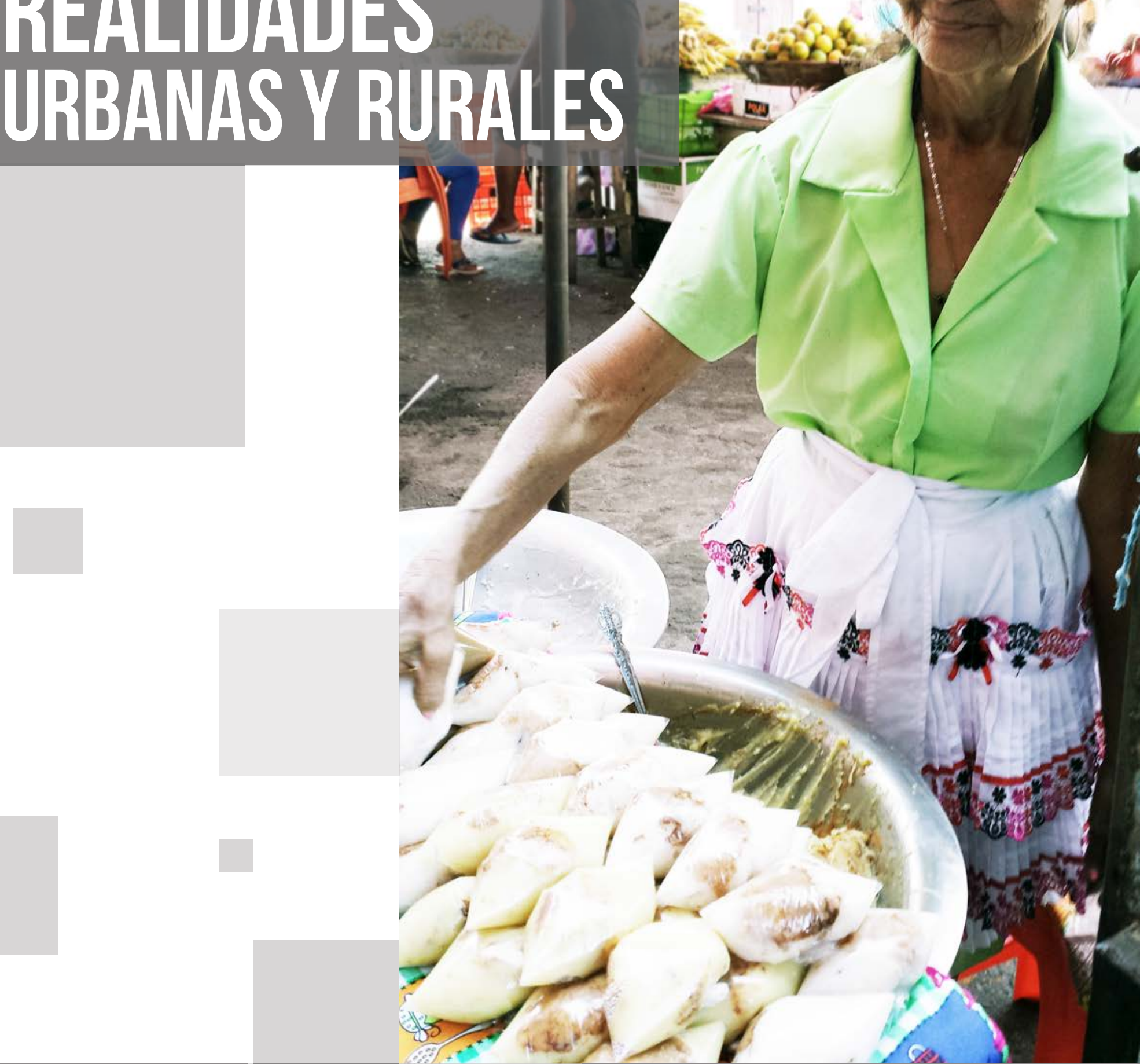


\title{
Detrás del estigma social: ser comerciante del Mercado Oriental de Managua
}

\author{
Norling Sabel Solís Narváez
}

\section{Resumen}

Para comprender a fondo el Mercado Oriental de Managua, el más grande de Centro América y el más importante de Nicaragua, es esencial conocer a sus protagonistas: los y las comerciantes, con sus múltiples expresiones identitarias y su cultura. Una frontera invisible y a la vez persistente divide este grupo social en dos grandes categorías: el comerciante fijo y el ambulante-eventual. Sin embargo, existe un aspecto de la identidad colectiva que pocas veces ha sido investigado e incluso tergiversado, por eso es muy importante comprender el origen de los y las comerciantes. Provienen de distintos lugares del país y el espacio que ocupan en el mercado y los productos que venden se relacionan estrechamente con su procedencia geográfica y sus raíces socio-culturales. Sin embargo, en la percepción de la opinión pública, la identidad del comerciante del Mercado Oriental sigue siendo influenciada por las generalizaciones y los prejuicios que se generan en la opinión pública. El objetivo de este trabajo es documentar a través del método etnográfico lo no documentado de este universo complejo y muy diverso: qué está detrás de la imagen estereotipada que se pregona en los discursos del gran público, asociando a la identidad del comerciante el estigma de graves problemas sociales.

Palabras Claves: Comerciante fijo, comerciante ambulante-eventual, identidad colectiva, redes sociales, estigma social, opinión pública.

\section{Abstract}

The Oriental Market of Managua is the largest popular market in Central America and Nicaragua's most important. To deeply understand the Oriental Market, it is essential to understand its main actors: the men and women venders, in their multiple expressions of identity and culture. An invisible and yet persistent border divides this social group into two large categories: the fixed vender and the mobile part-timer. However, there is an aspect of the collective identity that has rarely been researched and yet is very important: the origin of Oriental Market venders. They come from diverse parts of the country, and the space they occupy in the market, as well as the products they sell, relate closely with their geographic origins and their sociocultural roots. However, public opinion about Oriental Market venders continues to be influenced by generalizations and prejudices. The objective of this paper is to document the undocumented of this complex and diverse world, using the ethnographic method to find what is behind the stereotyped, stigmatized image that dominates public discourse of the vender's identity.

Keywords: Fixed vender, mobile/part-time vender, collective identity, social networks, social stigma 


\section{Introducción}

El Mercado Oriental es un lugar congestionado, extremadamente arraigado a lo que socialmente se ha construido. La misma población en general que no es parte del mercado, define al comerciante desde afuera, es decir desde su propia concepción y por supuesto percepción creada anticipadamente por la opinión y discurso público. Tanto así que se utiliza la palabra "mercadero o mercadera" para realizar ofensas a una persona que está eufórica, expresando de esta manera un transfondo de discriminación creado en el discurso público. Los comerciantes del Mercado Oriental son definidos en base a generalizaciones construidas a partir de la influencia de los medios de comunicación.

Existen dos miradas de la identidad del comerciante, es decir, desde lo que "ve" la sociedad en general, y lo que a lo interno se "ve" e interpreta entre los comerciantes, es decir, las distinciones que plasman los mismos. Esas distinciones están expresadas en el espacio físico y social en el que se desarrollan de manera que sus dinámicas responden a las relaciones establecidas entre los grupos sociales.

Es importante señalar que la influencia de las relaciones en los comerciantes configura la realidad misma a la que están inmersos. La relevancia que tienen las influencias sociales para orientar a los nuevos miembros a actuar, sentirse y ser un comerciante que responderá a una lógica similar a la que responden los miembros de su grupo de parentesco consanguíneo y afinidad.

Se aborda los aspectos de identidad de los comerciantes desde un sentido antropológico, aterrizando en un análisis de los elementos socioculturales de los comerciantes. Las características individuales y colectivas, que le distingue del "otro" comerciante, entendiendo a este otro como el individuo que comparte el espacio y ciertas actividades comerciales, donde incluso estas particularidades tienden a dar pautas a una forma de estigma social.

El estigma social será analizado desde las relaciones sociales en dos sentidos: relación entre sociedad y comerciantes, en la cual la primera es influenciada por los medios de comunicación y crea una identidad estigmatizada del comerciante, y segundo la relación entre comerciantes, cómo la influencia de "afuera" configura las relaciones sociales internas del mercado, produciendo en algunos casos exclusión social y marginación entre los comerciantes.

\section{Antecedentes de la investigación}

Cuando se abordan estudios relacionados a problemas sociales y estigma social dentro del Mercado Oriental, se podría decir que se logra recopilar mayores artículos de corte periodísticos que hacen alusión a tal fenómeno desde una óptica superficial y en todo caso desde fuera. Estos artículos de prensa y periódicos carecen de sentido científico y reflexión objetiva de la situación del Mercado Oriental.

Sin embargo para enmarcar los antecedentes de este trabajo investigativo, no se puede prescindir de las fuentes periodísticas que brindan información para reflexionar y analizar sobre la realidad del Mercado Oriental. Ante ello se hará mención de algunos artículos que hacen alusión al mismo mercado populoso.

En el 2010 sale a luz pública un artículo periodístico llamado "Mercado Oriental, monstruo que traga Managua" (El Nuevo Diario, 2010), el mismo hace referencia sobre el extremo crecimiento del mercado, visto como una amenaza sobre la ciudad capitalina. Durante la lectura de esta nota se percibe en total una mirada descriminadora, mas que preocupada de quien escribe. Lo mismo transmite al lector que en caso crítico lo que hará es posicionar un estigma de peligro ante el mercado.

Para el 2012 se realizó una nota de prensa en el mismo periódico antes mencionado, en el cual se hace referencia a una reseña histórica del Mercado Oriental, el mismo dice "El Mercado Oriental, vástago del terremoto de 1972" (El Nuevo Diario, 2012). Este artículo hasta cierto punto se visualiza como un aporte al conocimiento y la construcción de la memoria de la población, quien logra apreciar el surgir histórico del Mercado Oriental, sin embargo las notas donde se refleja el estigma van tajantes en el texto. En uno de sus apartado hace referencia al "mejor mercado" de ayer, lo que sugiere que el actual no es lo mismo.

Sin embargo es importante reflexionar que cuando se habla del "mejor" y "peor" mercado no se refiere especificamente al espacio físico del Mercado como tal, sino en todo caso a quienes componen este mercado, porque en caso no existir población que comercia en este espacio, no existiese el Mercado Oriental, es por ello que cuando se estigma, no se estigma al Mercado como espacio independiente a los comerciantes, sino al Mercado como un espacio de comerciantes. 
Otro artículo encontrado hace referencia a un tema redundado dentro de las notas de prensa, es decir, el llamado "reordenamiento en el Mercado Oriental". Este artículo periodístico fue publicado en el 2013, por el Nuevo Diario, en el mismo se encuentra apreciaciones de la población compradora que llega al Mercado y expresa su inconformidad con los vendedores ambulantes. Lo que infieren en el artículo, es que el "reordenamiento" supone un desplazamiento de quienes venden en estado de precariedad, dicho en otras palabras, es mover a los comerciantes ambulantes que venden en extrema condición de riesgo, hacia otro espacio con "mejores" condiciones. Sin embargo, los comerciantes ambulantes no se convencen de esta movilización puesto que su vida social y cultural ha sido construida en el único espacio que han conocido por años. Además comprende una lógica económica ya que venden al cliente los productos que están a un mayor costo en otro lugar, facilitando la adquisición de productos. Es decir crean una especie de red mercantil donde se desplazan ambulantemente.

Otro trabajo más reciente representa una investigación sistemática realizada en el contexto del Mercado Oriental. Se posiciona como un primer artículo de corte científico-social en el marco de la ciencia antropológica. Se titula "Comerciantes, corredores y marchantes: el Mercado Oriental de Managua como espacio de interacción social" (Narváez, 2014) en este estudio se reflexiona entorno a la percepción del Mercado Oriental como un espacio vivo de relaciones sociales, que genera y construye realidades socioculturales de los actores sociales que en este espacio convergen como los comerciantes fijos y ambulantes. Además realiza una reflexión socio-analítica de como se funden las relaciones entre los comerciantes partiendo del núcleo familiar y extendiéndose hasta las relaciones de alianzas entre los comerciantes e incluso las relaciones entre los comerciantes y clientes para generar los llamados marchantes, quienes aseguran un cliente que será un generador de ingresos casi fijo para el comerciante.

\section{Apuntes teóricos que enmarcan el estudio}

El Mercado Oriental es un espacio de manifestaciones culturales, un mosaico de expresiones lingüísticas y características ancestrales, que se combinan con los elementos propios de un mercado moderno, pero con la misma raíz indígena de un mercado tradicional, evi- denciado en los canastos y la misma forma de organización de los comerciantes de perecederos.

De forma que es importante retomar la definición de cultura porque cada comunidad tiene características particulares que se expresa en su cultura que la hace única y particular del resto, en el que su vida cotidiana es producto de un proceso de socialización (Krotz, 1994). En ese caso es necesario ratificar que las comunidades poseen culturas propias, pero también que cada individuo se identifica con la cultura que adquirió durante el proceso de socialización en su vida.

Ciertamente la cultura es "el espacio semántico en el que los seres humanos se construyen y representan a sí mismos y a los otros y por tanto a sus sociedades y a sus historias" (Rota, 2009, pág. 10). Por tanto la cultura es el conjunto de elementos identitarios siendo material e inmaterial, legítimos y regulizadores que adquieren a través de un proceso de socialización de dichos elementos que caracterizan a un grupo o comunidad.

El cuestionamiento sobre las bases de la cultura de una comunidad y la identidad individual y colectiva de los miembros parte en esencia del grupo familiar en que se encuentran, que son en primera instancia una forma de conectar con los demás miembros de la sociedad, expresado a través de las relaciones sociales.

Los mercados en su interior están compuestos de relaciones permanentes entre los individuos con particularidades culturales, geograficas e históricas. Es importante definir como se desarrollan estas relaciones comerciales y en caso preciso del contexto de estudio, se desarrollan en un espacio conocido como tramo, tiendas, sombrillas, mesas, canastas y otros espacios configurados de compra y venta que a su vez este compone el mercado, como un espacio de fluidas relaciones sociales y comerciales.

Por tanto es evidente retomar el espacio y la actividad de los comerciantes como un elemento de trascendencia e importancia históricas e incluso para definir el origen de su identidad. Los mercados nacionales en su condición actual son una forma híbrida, esto sugiere que son parte de los pueblos periféricos como de las ciudades.

Para lo que Valenzuela infiere que "El comercio y los mercados han funcionado históricamente fuera de la sociedad en lugar de dentro de ella, es decir, como sistemas accesorios del modelo global cultural. El comercio a 
a larga distancia es previo al comercio interior, a mercados segmentados y con fuertes restricciones rituales para garantizar tanto la paz del mercado como para evitar su extensión indiscriminada.) (Molina \& Valenzuela, 2006, pág. 50).

El autor en esta cita infiere que el mercado es más complejo que un solo espacio territorial, es decir está comprendido como ese espacio específico de relaciones directas, a lo que el autor llama "mercados segmentados" (Molina \& Valenzuela, 2006) por lo que este da cabida en un aspecto más complejo a mercados globales; de dimensiones más generales; de poblaciones que se relacionan comercialmente de un lugar a otro más retirado.

Esto completa las funciones de los mercados como espacio de economía y distinción de identidades entre quienes están en el "círculo de mercado" y el público que entra en el mismo. En todo caso "Es posible distinguir diferentes tipos de mercados: mercados primitivos y/o campesinos, en los que se obtiene un complemento de la economía doméstica, mercados locales con la presencia de comerciantes especializados y mercados regionales, regulados o no, conectados a una amplia red geográfica." (Molina \& Valenzuela, 2006, pág. 59).

Existen mercados que funcionan dentro de las economías domésticas, como el caso del Mercado Oriental, porque su función directa es vender a la población que necesita algún producto de uso doméstico como el caso de verduras para la comida. Sin embargo en este mercado también hay particularidades de mercado regional, por la importancia a nivel centroamericano.

El Mercado Oriental funciona al por mayor para clientes que no responden directamente a un uso doméstico, es decir, existe esa variable importante dentro del Mercado Oriental, el que también responde a lógica de microeconomías, cuando el cliente compra ropa por ejemplo al por mayor, este luego en su localidad la vende. Sirviendo el Mercado Oriental como proveedor de bienes para las microeconomías. Esto sugiere que dentro del Mercado Oriental se perciben más mercados que conviven a lo interno, y que todos están estrechamente vinculados.

El carácter de relaciones comerciales y relaciones personales, se encuentra directamente vinculados a la identidad de quienes confluyen en ese espacio. Es decir quienes visitan el Mercado Oriental, van con objetivos y necesidades propias, pero que de forma más general caracteriza a los grupos sociales. Así que la identidad individual también cumple funciones colectiva de forma que se representa a nivel más macro en identidad colectiva.

Lo que se logra en "La pertenencia a un grupo se da como resultado de un proceso de categorización en el que los individuos van ordenando su entorno a través de categorías o estereotipos que son creencias compartidas por un grupo, respecto a otro..." (Maldonado \& Hernández , 2010, pág. 233), sin embargo además de los aspectos subjetivos mencionados por el autor, también complementaría el espacio y la configuración del mismo por quienes socializan en él.

De forma que el mercado también se vuelve un espacio de identidad colectiva, precisamente porque varias identidades individuales componen este sector. Identidades que vienen de distintos puntos y localidades, que traen una cultura, y que hace que esa cultura quede en evidencia en el Mercado pero que además se converge con las demás identidades creando de esta manera, el conjunto macro, lo que se percibe como esa identidad colectiva del Mercado Oriental.

Los miembros de los respectivos grupos comparten características idealistas y subjetivas que conforman y articulan al grupo en un espacio físico y social. Identificarse con el grupo es tener una relación vinculante a su identidad individual, porque parte del principio de las relaciones establecidas con los demás miembros del grupo que tienen particularmente una identidad con fines comunes dentro del grupo social.

Los miembros que se afilian a un grupo social buscan un propósito común, el reconocimiento de "ellos" en relación con los "otros", esta particular relación, se logra a través de las relaciones sociales que comprenden distintas formas de construir una identidad individual, enmarcada también dentro de una identidad colectiva y eso se transfiere de un individuo a otro, por eso las relaciones sociales son:

"Las relaciones interindividuales entre hombres y mujeres se inscriben por lo tanto en el marco de las relaciones sociales globales que estructuran las relaciones de fuerza dentro de la sociedad, relaciones de sexos y relaciones de clase. Esas relaciones se presentan como estrechamente ligadas: interactúan las unas sobre las otras y juntas estructuran el conjunto del ámbito social."(Pfefferkorn, 2007, pág. 55) 
Para efecto de comprender lo anteriormente dicho, los miembros de un grupo se relacionan entre ellos, pero se abstienen con otro grupo que no responde a sus intereses por lo que es necesario definir que existe exclusión social "como un proceso multidimensional, que tiende a menudo a acumular, combinar y separar, tantos a individuos como a colectivos, de una serie de derechos sociales tales como el trabajo, la educación, la salud, la cultura, la economía y la política, a los que otros colectivos sí tienen acceso y posibilidad de disfrute y que terminan por anular el concepto de ciudadanía..." (Ramírez, 2008, pág. 179)

Lo que implica en todo caso legitimar por las condiciones sociales que existen en los grupos, en un mismo espacio rural-urbano, el mercado se vuelve un singular contexto donde existen tantos grupos como identidades colectiva, esto a menudo significa reconocerse ante los demás y desconocer a los demás. Esto desde la antropología comprende la otredad en términos étnicos, pero es aplicable en el sentido de reconocimiento del "otro" y "nosotros" en términos socioculturales en contexto urbano.

El mercado es un espacio donde se visualiza el reconocimiento de las identidades grupales de forma endógena y el desconocimiento del "otro", esto quiere decir que a lo interno los comerciantes están segmentados y entre ellos reconocen esa segmentación lo que ocasiona que no se reconozca al otro comerciante. Por ejemplo un comerciante fijo del Mercado Oriental puede decir que es comerciante fijo porque paga, y tiene un espacio con infraestructura, pero no acepta que se le compare con otro comerciante que no es fijo, es decir un ambulante.

En todo caso lo que se interpreta de este fenómeno de relaciones sociales e identidad es que la exclusión y estigma social forman parte de las relaciones de identidades construidas a través de los discursos externos. En ello influyen directamente los medios masivos de comunicación, que directamente aportan a la construcción estigmatizada de la identidad del "otro", es decir de aquel que no cumple con los parámetros de un comerciante fijo.

Es importante reconocer como "si se tiene control de los medios de información y el sistema educativo y la intelectualidad es conformista puede surtir efecto cualquier política" (Chomsky \& Ramonet, 2002), en ello radica la manipulación y manejo de las percepciones del pú- blico. Es decir los medios de información construyen un discurso para un público específico de la sociedad, pero que a su vez margina a otro del cual se habla.

En todo caso, es lo que ocurre con la marginalidad del contexto en estudio, producido y reproducido por los medios masivos, que en su afán de vender información, ocasionan distorsiones en la imagen de los comerciantes del Mercado Oriental. Es decir la gente percibe una imagen tachada del comerciante porque observa y escucha lo que los medios de comunicación dicen de ese comerciante. Entonces la discriminación se proyecta a los sectores y se reproduce a lo interno del mercado.

\section{Metodología del proceso de investigación}

El presente artículo es producto de los estudios realizadas en campo durante el curso de la licenciatura en Antropología Social, logrando sistematizar el trabajo realizado desde 2013-2015 y su reflexión en el 2016. La investigación sintetizada en este artículo es un sub-aspecto de la investigación final presentada para defender la titulación. El contexto para el trabajo de campo fue el Mercado Oriental. El enfoque utilizado para la realización de dicho trabajo es el cualitativo de corte etnográfico. El enfoque dirigido a través de la etnografía permite una reflexión y análisis a partir de la observación del contexto de investigación y desde la percepción de los sujetos sociales.

En ese sentido es que "toda investigación social se basa en la capacidad humana de realizar observación participante. Actuamos en el mundo social y somos capaces de vernos a nosotros y nuestras acciones como objetos de ese mundo." (Hammer \& Atkinson, 1995).

Haciendo uso de la observacion participante y escuchando las voces de los actores sociales, se reflexionó entorno a un problema o fenómeno social invisible ante los ojos de la sociedad, pero sensible para los actores sociales del contexto de investigación: la percepción y opinión del público sobre los comerciantes del Mercado Oriental. Este enfoque procura "crear una imagen realista y fiel del grupo estudiado, pero su intención y mira más lejana es contribuir en la comprensión de sectores o grupos poblacionales más amplios que tienen características similares” (Miguélez, 2005) 
Para este trabajo se hizo énfasis en la observación de la cotidianidad de los comerciantes, estando en el terreno de dos a tres semanas con ellos, por tres años, es decir que al año se le dedicaba visitas de dos a tres semanas compartiendo con los comerciantes y luego visitas esporádicas con los informantes claves. Este proceso permitió observar la cotidianidad de los comerciantes fijo y ambulantes para entender la cultura dentro del mercado. La mayor dificultad presentada en este espacio de investigación es que se debe tomar en cuenta que los comerciantes son bastante tímidos al momento de realizarles pregunta y el tiempo se debe considerar puesto que su dinámica les obliga a estar al tanto del cliente, por ello las entrevistas deben ser precisas y con un léxico adecuado según el informante, para que el mismo sepa lo que se le pregunta y la respuesta que dará.

Para la recolección de la información se aplicaron tres instrumentos: 1) guía de entrevista para comerciante fijo, 2) guía de entrevista a comerciante ambulante, 3) guía de observación. Se aplicaron 10 entrevistas y se generaron casi 15 conversaciones informales. El criterio de selección de informantes era: a) que tuvieran más de 5 años trabajando en el Mercado Oriental, b) que fueran comerciantes ambulanteseventuales, c) que fueran comerciantes fijos, d) que tuvieran en el rango de edad entre 25 a 60 años.

Luego de aplicar los instrumentos se dio el proceso sistémico: procesamiento, discusión y reflexión de los datos encontrados, para luego ser traducido e impregnado en un discurso analítico mediante un informe de investigación como resultado del trabajo de campo.

\section{Resultados}

\section{Acerca del origen del Mercado Oriental}

La historia nos remarca el interesante origen del Mercado Oriental en Managua. Los datos históricos registrados en la municipalidad de Managua detallan que este mercado comienza a construirse en el año 1936 con un primer galerón, ocupando apenas un espacio aproximado de una manzana. El Mercado Oriental, considerado el más grande de Centro América, tiene una extensión aproximada de 52 hectáreas, en las que se ubican tiendas, distribuidoras, comedores, vendedores fijos y ambulantes-eventuales. Se encuentran los servicios básicos: agua y luz de los cuales los comerciantes hacen uso pagando impuestos a la Alcaldía de Managua a través de COMMEMA (Corporación Municipal de Mercados de Managua).

El Mercado Oriental es sin duda uno de los más importantes a nivel nacional. Su vasta población de comerciantes lo hace un importante centro de flujos comerciales. Dentro del Mercado Oriental existe un espacio delimitado y distribuido en tres zonas administrativas por la municipalidad de Managua, pero este ha logrado desarrollar otros senderos aledaños en parte del mercado, en donde se logra encontrar negocios y/o comerciantes en la dinámica de comercio, que históricamente ha funcionado.

La memoria histórica de las personas lleva a visualizar el paisaje del Mercado durante sus inicios. Doña María Urbina (q.e.p.d), una de las primeras comerciantes de este mercado, da una idea de lo que fue. Doña María era ${ }^{1}$ una señora de estatura baja, cabello blanco, mirada serena y firme, de 85 años aproximadamente. De voz pausada, de audición tenue. De origen sencillo proveniente del campo, una señora que al paso del tiempo demostró que ser comerciante te lleva a crecer económicamente como espiritualmente, sin olvidar sus raíces campesinas indígenas. Comenta:

"Vine a este mercado creo que para 1940. Recuerdo que me trajo mi mamá bien chiquita. Antes habia un solo galerón, habian, por ahí, varias casas de madera $y$ de tejas de barro donde estaban gente que tenía ya una ventecita más o menos de abarrotes, una especie de pulperías, y en el resto del terreno, estaban la gente que venía del campo en sus carretas jaladas por bestias $y$ otras por personas, en ellas traían frutas y verduras de las finca. Una señora que vendía cerca de donde nos poníamos nosotros, decía que algunos venían de la finca Las Sierras. Antes sólo había el Mercado Bóer y el Mercado San Miguel, este último estaba más céntrico. Pero con el terremoto de 1931, mucha gente ya ocupaba este espacio que era un gran solar. Al suave la gente empezó acomodarse aquí. Recuerdo muy bien que nosotros en el suelo nos poníamos con una canasta a vender chinelas y cositas así, para el sustento. Te digo, estaba chiquita y lo recuerdo como si fuese ayer." (Urbina, 2013)

1 Entrevista realizada en el año de 2013, antes de su fallecimiento en el año 2015 
En la memoria de los pocos comerciantes de esa época que aún viven, se recuerda ese mercado pequeño, donde sólo unos cuantos llegaban a vender. Pasaron los años y el mercado fue avanzando en sus estructuras físicas, y sobre todo en su popularidad. Terminada la Segunda Guerra Mundial, los datos encontradas en fuentes de artículos periodísticos (END, 2008) indican que en ese periodo se da un mayor desarrollo en el pequeño mercado de ese momento. En los años 50 'y 60 'este mercado va desarrollando, ya habían más comerciantes y casas alrededor. Ya estaba acercándose a un centro comercial importante.

Pasado el tiempo, llegando a 1970, el mercado funcionó como un centro importante de reuniones para los guerrilleros del Frente Sandinista de Liberación Nacional. En los recuerdos de Pedro Castellón se menciona "aquí se reunían algunos guerrilleros, casi nadie menciona que el mercado jugó un papel importante para la Revolución Sandinista, diría yo que es un pequeño vacío, aunque toda Nicaragua participó. El mercado por sus entradas y salidas, y puestos la gente resguardaba a los guerrilleros e incluso hubieron quienes hasta guardaban armas" (Castellón, 2016)

La información indica el grado de importancia histórica del Mercado Oriental, pues esto consolida el hecho de que no sólo funge, ni fungió como un simple centro comercial, al contrario resguarda una memoria colectiva en los recuerdos de los terremotos y revolución del país. Dentro de este proceso histórico que atravesó Nicaragua, los comerciantes estaban viviendo el momento, es decir el hecho transcendental e histórico fue vivido en cada rincón de Nicaragua, incluso los mercados en su espacio, con sus características sociales y culturales.

En 1972 ocurre el terremoto en Managua, esto configuró la vida y proceso de los comerciantes del Mercado Oriental. Las personas reconstruían una vida, pero además un espacio que les permitía sobrevivir. Recuerda doña Huguette Vega, comerciante y hoy en día Vice Gerente de COMMEMA del Mercado Oriental, "fueron días duros, se vivía un proceso duro en Nicaragua, y los comerciantes vieron los estragos que causó el terremoto. Después del terremoto y el triunfo de la Revolución, el mercado fue a poco reestableciéndose. Para este momento crucial en el país, el triunfo de la Revolución, el mercado se volvió la principal fuente de ingreso, muchas familias se fueron al mercado a buscar el pan de cada día. Aquí había ricos, pobres, de todo.

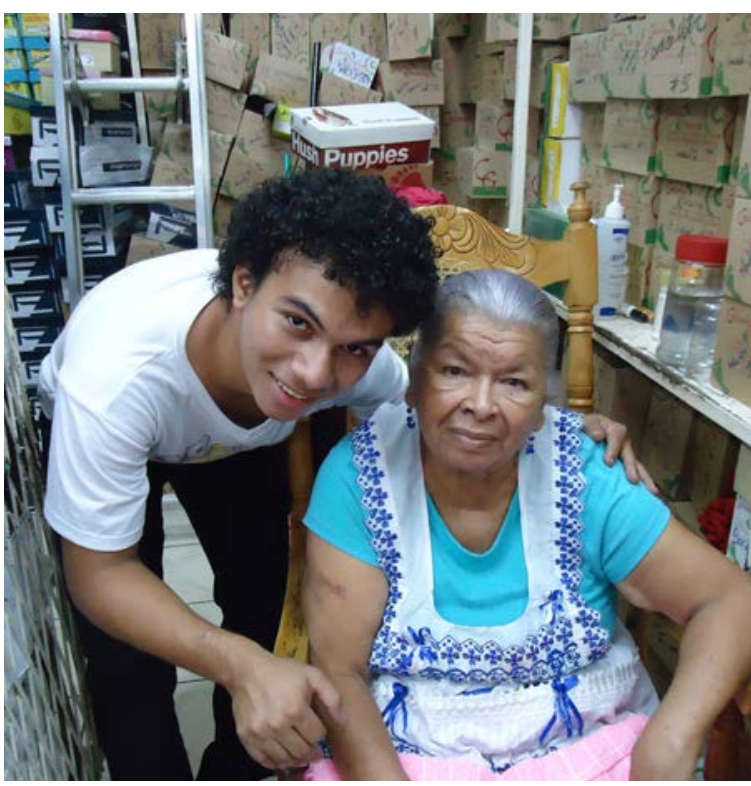

Foto tomada en el tramo de doña María Urbina (q.e.p.d), comerciante fundadora del Mercado Oriental. Entrevista realizada en 2013.

El terremoto había hecho desastres. Surge la guerra contrarrevolucionaria que ya sabemos fue patrocinada patrocinada por el imperio yankee, y perdemos el gobierno para los $90^{\prime} y$ en ese momento ocurre una compactación de los trabajadores del Estado, todos los que éramos simpatizantes y militantes del Frente (F.S.L.N) nos despiden. Regresamos a las casas sin empleo ni donde trabajar, y la alternativa fue el Mercado Oriental para muchos incluyéndome, aunque yo ya tenía una vida hecha desde chiquita en el Mercado Oriental, porque crecí siendo comerciante aquí con mi familia, y pues me toca regresar con mi gente. $Y$ así hubo un sin número de ex trabajadores del Estado que se vinieron a vender lo que sea al mercado. Ahí ocurre una expansión más en el Mercado Oriental. Y aumentó si te fijas durante el periodo neoliberal." (Vega, 2014)

La historia revive las emociones de los sujetos, "la memoria individual existe, pero ella se enraíza dentro de los marcos de la simultaneidad y la contingencia. La rememoración personal se sitúa en un cruce de relaciones de solidaridades múltiples en las que estamos conectados. Nada se escapa a la trama sincrónica de la existencia social actual, y es de la combinación de estos diversos elementos que puede emerger lo que llamaremos recuerdos, que uno traduce en lenguaje." (Betancourt Echeverry, 2004) 
Por ello es importante retomar la memoria individual, que se convierte en la memoria colectiva, cuando el individuo utiliza en el discurso vivencias propias y las relaciona con momentos históricos que ocurrian simultáneos a su experiencia. En los relatos de los informantes se percibe la construcción del discurso reforzado en la memoria y recuerdos ocultos de él, pero complemetados con los recuerdos y experiencias de otros sujetos mismos del mercado. En cuanto a la historia del Mercado Oriental no se puede dejar desapercibido los elementos que lo conectan con la historia general y la memoria colectiva de los pobladores de Managua.

\section{Mercado Oriental entre lo moderno y tradicional}

Hablar de mercados populares, es hablar de tradición, cultura, elementos sociales y económicos que están vigentes en distintos contextos de varios países latinoamericanos. El mercado está configurado entre tantas realidades que construyen una sola realidad, un mercado en dicotomía entre moderno y tradicional. Lo moderno, encontrado en productos tecnológicos de nivel transnacional e internacional, visto en las tiendas y sus variedades, se observa en los comerciantes de otras nacionalidades vendiendo en este espacio del sector popular. Lo tradicional configurado por las poblaciones rurales y urbanas que venden y ofertan productos producidos desde cada núcleo familiar, vendiendo en canastos y carretones desde verduras hasta las fajas de cueros que hacen en las zonas rurales de la capital y otros departamentos. Un mercado que no está en la periferia de la capital en la actualidad, pero se vuelve punto de gestión de poblaciones que se encuentran en los municipios y periferias de la zona capital.

Haciendo referencia a la antropología como el estudio del comportamiento humano, que refleja la cultura indígena impregnada en las nuevas poblaciones, es importante analizar el origen común de los mercados latinoamericanos, este origen es necesariamente prehispánico. Negar que los pueblos latinoamericanos no tuvieran una plaza donde intercambiaban productos que obtenían de sus patios es negar la raíz indígena prehispánica de su identidad.

México fue sede de distintas culturas indígenas que desarrollaron sistemas de organizaciones importantes antes, durante y después de la colonia, la principal corriente indígena de pueblos autóctonos establecidos en el Pacífico de Nicaragua fueron de origen mesoamericano, partiendo de México hasta Guanacaste y Nicoya en Costa Rica. La organización de las plazas comerciales de distintos pueblos ancestrales, tenían distintos tipos de formas de relación, en base a intercambios prestaciones y servicios entre los miembros que participaban de los tiangues.

"Cholula estaba organizada alrededor de una administración religiosa del Templo de Quetzalcóatl, intimamente vinculada con el comercio de larga distancia." (Towell \& Attolini Lecón, 2009, pág. 187)

Las relaciones entre comerciantes, aunque estos sean con personas que no pertenecen a su grupo, lograron ser fundamento de grandes intercambios que establecían en principio lazos más allá de ser comerciales eran sociales. Es interesante analizar este aspecto en el cual se observa que esta tendencia no ha variado considerablemente, pues actualmente en los mercados populares la idea de intercambios fuera del espacio en el que se encuentran los mismos comerciantes es un punto de partida para lograr aliados o relaciones sociales que ayuda a la estabilidad en el mercado.

En las comunidades prehispánica incluso existieron las relaciones sociales y económicas, vistas como intercambio, tributos o alguna espacie de trueque, dar lo que producían a cambio de un bien o servicio de la contra parte. Esto daba prestigio, bendición, aliados

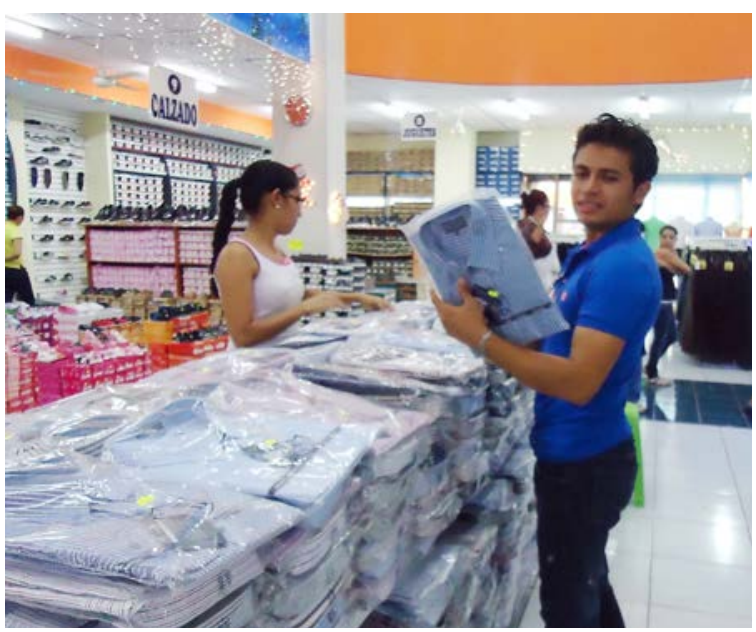

Foto de tramo extenso, con estructuras complejas, tienda de dueños extranjeros. Foto realizada durante trabajo de campo en 2015. 
para las guerras en fin cualquier relación que estableciera lazos entre dos grupos sociales. Aunque este elemento será importante para el resto de la investigación, los grupos pueden relacionarse entre sí, pero eso no implica que compartan identidad estrictamente, pueden comprender algunas pautas culturales que no son fundamentales de tronco de identidad común.

El entramado social encontrado en el Mercado Oriental conserva elementos socio-culturales cuyas raíces están firmemente sujetas a los mercados tradicionales indígenas. Las estrategias de mercado, como el cantar sus productos, vender con canastas en el suelo o establecer relaciones de intercambio y reciprocidad con familiares y otros aliados son reminiscencias claras de una tradición ancestral presente aún en la vida cotidiana del mercado.

Los mercado funcionan en la construcción de identidad como espacio social, (Bolívar \& Erazo Espinosa, 2013). Otras investigaciones en contextos latinoamericanos se relacionan con el expuesto en este trabajo "al llegar por la carrera frente a la plaza, hay casetas de vendedores ambulantes, haciendo gala de sus mercancías: zapatos, bolsos, cosméticos... y la famosa fantasía." (Solano, 1994). La descripción realizada no está ajena al contexto nicaragüense. Por tal razón se comprende como los comerciantes del Mercado Oriental, tienen características comunes, ya que este es un espacio lleno de matices populares comunes y eso es el reflejo de la corriente indígena en Latinoamérica. Incluso el elemento de comerciantes ambulantes o vendedores tradicionales como el que se explica. (Garza, 2011)

\section{Ser comerciante del Mercado Oriental}

El comerciante es producto de un conglomerado más amplio y complejo de relaciones sociales, de configuración social, de redes de intercambios reinterpretadas a través del tiempo y estructuras sociales. Es un ser social y económico que configura su realidad, redefiniéndola como estrategias de supervivencia para resistir los cambios de los sistemas socioeconómicos del país.

Según las definiciones dadas por los mismos informantes, se encuentra que el comerciante es:

"Una persona que se gana y juega dinero diario, invierte, gasta, compra, gana y no gana..." (Elba García)

"Trabajador que por su propia cuenta quiere levantarse un poco su nivel...Es una forma de vivir, es mi trabajo, así me gano la vida..." (Georgina Cruz)

"Es una forma de trabajo, lo que hago para vivir y así vivo yo...Comerciante es una persona trabajadora y capaz de salir adelante es una persona hábil y capaz de hacer metas" (Miguel Salvador)

Según las definiciones que los mismos comerciantes dan, se resuelve en un sistema complejo de relaciones sociales, económicas, religiosas para subsistir al cambio de sistemas comerciales capitalistas. En todo caso para analizar al sujeto de esta investigación es importante introducirse a los callejones del Mercado.

Ganarse la vida no sólo es un simple dicho, sino un conglomerado de actividades que lleva intrínseca una identidad sociocultural del comerciante. El comerciante se define como un ser flexible y versátil a los procesos y cambios sociales. Se diferencia con otros que están en el mismo espacio, tratando de conquistar a un cliente y volverlo su "marchante" (Narváez, 2014), sin embargo esto para que suceda necesita de estrategias que van desde llamarlos y enamorarlos, hasta anteponer la religiosidad de algunos.

La cultura construida por lazos de parentesco y alianzas de grupos está configurada por la mirada interna y externa del comerciante del Mercado Oriental. No es un simple ser social con su grupo de pertenencia, sino en un sentido más complejo, responde a un ser social versátil logrando relacionarse con personas desconocidas todos los días como parte de su cotidianidad.

El comerciante de este mercado que responde a distintas connotaciones: fijo (tramos y canastas), y ambulantes (carretones y menudeo) se desarrollan dentro de un espacio que se resignifica diariamente. Dentro de este Mercado, las actividades cotidianas comienzan para algunos a las $3 \mathrm{am}, \mathrm{y}$ termina a las $6 \mathrm{pm}$. Pero también a quienes empiezan a las 8 de la mañana y terminan a las 4 o 5 de la tarde, como un centro laboral de 8 horas con condiciones. Sin embargo se encuentra el que vive dentro del Mercado Oriental y este posiblemente trabaje durante el día y parte de la noche. 
Esto responde a una lógica de dinamismo y activismo comercial dentro del Mercado Oriental para no perder el espacio que se ha ganado. El Mercado Oriental como espacio de relaciones comerciales a nivel nacional e incluso regional se configura como un centro importante de fluctuaciones de bienes, servicios y dinero.

Básicamente lo que antes empezó con tres galerones, conformando una economía local, se transformó en la inmensa masa de comerciantes informales, que hoy el Estado trata de "reordenar" por medio de COMMEMA para controlar a los mismos en un tipo de "comercio formal" en su condición misma de informal según la definición de Isidoro Moreno (1997). No es la excepción en Nicaragua, que se trate de controlar un espacio informal por parte de políticas públicas de ordenamiento territorial, puesto que hay ejemplo claros, como el caso de Tepito en México, un barrio popular con un mercado popular que por cierto tiempo se ha resistido al control "formal" por parte del Estado (Maerk, 2010).

Los comerciantes en el Mercado Oriental (principalmente los ambulantes) se resisten a ese control total por parte del Estado. Los comerciantes de mercados populares funden una masa popular que se resiste a las relaciones comerciales formales, controladas a través de impuestos y políticas de movilización. La resistencia en contra incluso de los medios masivos de información, pero esta lucha se ha gestado a través de la lógica sociocultural de adaptación de su cultura a las necesidades que demanda los cambios en la sociedad.

La cultura de los comerciantes les permite ser seres sociales, como menciona Wilmer Cruz (16/04/13) uno de los informantes. Lo social permite que el nuevo miembro del Mercado entienda su mundo, es decir, las nuevas generaciones configuren su realidad con la misma versátilidad de sus padres.

\section{Ser comerciante fijo}

Las distinciones socioculturales de los comerciantes en el Mercado Oriental, comprenden dos sujetos: los comerciantes fijos y comerciantes ambulantes-eventuales. Se caracterizará en este acápite a los comerciantes que pagan impuestos, los que para COMMEMA son fijos en el espacio.

Para interpretar esta asignación se retoman palabras del Lic. Augusto Rivera, Gerente General de COMMEMA, quien considera que "Los comerciantes fijos, estos son los que pagan su mensualidad de forma legal, se inscribieron y por esa razón tienen derecho a tener sus tramos pero claro según las normas...)" (A.R. $09 / 05 / 14)$

Las autoridades de COMMEMA definen como agentes económicos a este tipo de comerciantes, al decir que son "clientes fijos" indican que son parte de una estructura socioeconómica dentro del mercado. Esencialmente por poseer módulos (tramos), que los distinguen del resto de comerciantes, lo que significa que este tiene derechos otorgados por la institución administrativa.

En este sentido comprenden los comerciantes fijos a todo aquel comerciante que logra pagar mensualmente una cuota impuesta por las autoridades municipales. En este grupo de fijos entran comerciantes de canastas, de tramos de ropas, zapatos, casas comerciales, etc.

Darling Pérez, administradora de tramo extenso (Narváez, 2014), menciona un aspecto relevante acerca de los espacios, afirmando que "uno siente que todo es de uno, es mentira pues ocupamos un espacio que COMMEMA nos está cobrando, así que sólo somos dueños de los módulos nada más." (D. P. 10/05/14)

Los comerciantes fijos, es el grupo social al cual pertenecen los vendedores de tramos simples y extensos (Narváez, 2014). Los tramos simples son aquellos con estructuras sencillas, sin grandes acabados urbanísticos, además de los que venden con mesas y canastas que pagan a COMMEMA por su espacio. Los extensos son los tramos con estructuras más complejas y amplias, en esta categoría entran las tiendas y casas de electrodomésticos.

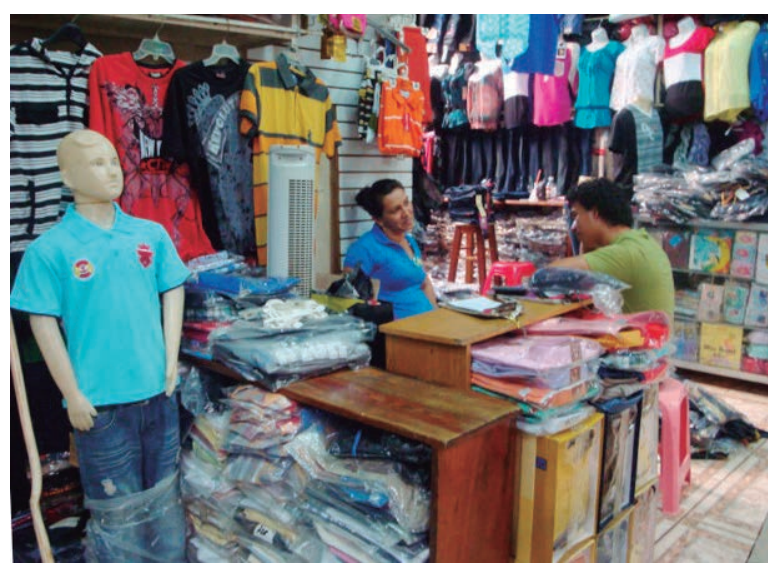

Foto de tramo extenso, con estructuras amplias y modernas. Foto de entrevista realizada en 2014. 
En este grupo las relaciones sociales están compuestas por elementos de intermedios, es decir las relaciones sociales entre los miembros de este grupo existe por vinculaciones directas de comercialización, en este caso los intermedios que vinculan un comerciante con otro son llamados corredores (Narváez, 2014). Tienen un sentido más del sistema capitalista de generar excedente de capital, obteniendo mayores niveles de adquisición.

Aunque son un sector más privilegiado dentro del mercado Oriental, su imagen como comerciante se percibe codificada por los medios masivos de información y las expresiones estigmatizadas de la población. Es decir que aunque son un sector con nivel de adquisición más alto en relación al resto de los comerciantes que también convergen en este espacio, su imagen se verá tachada y generalmente mencionada entre los chistes de la población para referirse de forma despectiva a una manera de comportamiento.

Sin duda referirse al comerciante fijo se debe tomar en cuenta, su cultura material definida desde sus tramos, productos que venden y los elementos que colocan para distinguir su identidad entre el resto de la población, por ejemplo el delantal como un medio de distinción entre los miembros del tramo. El delantal indica quién es el dueño del tramo y quiénes son los empleados o trabajadores.

El comerciante fijo que se encuentra distribuido por cada zona del Mercado Oriental, constituye una construcción cultural compleja de sentimiento de pertenencia hacia un grupo social, es decir que aunque pertenezca a una misma zona, e incluso al conglomerado de comerciantes que vende cierto producto, generalmente no tendrá un sentido de pertenencia en relación a un grupo, puesto que su interés más que una interacción con los comerciantes es una interacción de interés hacia los clientes, aunque esta aseveración no generaliza a todos los comerciantes, claramente existen comerciantes fijos que tienen un sentido de pertenencia hacia un grupo determinado dentro del mercado.

\section{Ser comerciante ambulante-eventual}

Entre los tramos, callejones y encrucijadas del Mercado Oriental, existe un sector mayoritario, que está en total contrastes con los anteriores comerciantes descritos. He aquí la otra cara de la moneda en el mercado, una cara distinta en todas las dimensiones posibles, desde los aspectos lingüísticos a los orígenes socia- les y culturales. El resultado de una configuración de contrastes, desde quienes se considera es el sector más vulnerable del mercado.

Compuestos por familias disertadas, es decir, que los comerciantes de este sector, viven en condiciones precarias, no tienen una estructura familiar saludable, padres violentos, o en casos críticos delincuentes, en medio de todo se percibe el reflejo de una niñez en riesgo. Niños quienes presentan el riesgo de tener condición delincuencial, ser víctimas de violaciones, ingerir drogas y otros tipos de estupefacientes.

Son familias de orígenes humildes, sectores marginales, que no alcanzaron una educación media o superior, que se han desenvuelto y desarrollado en un espacio de mercado popular, de donde sienten son parte y no pueden ser rechazados. Encuentran en el Mercado Oriental su lugar. Aunque luchan con restricciones mas complejas y fuertes que los comerciantes fijos, son choque directo de quienes resisten a la sociedad pero además de quienes resisten a las fuerzas internas del mismo mercado.

Para el informante Augusto Rivera, Gerente General de COMMEMA:

"Los comerciante eventuales, este paga una mensualidad mínima, no se le cobra mucho debido a su condición pues ellos pueden tener una canasta y estar en una esquina (...) están los comerciantes ambulantes estos son como los eventuales pero ellos están fuera de pago pues no tienen puesto ni tramo ni un lugar específico en donde vendan" (Lic. A.R. 09/05/14)

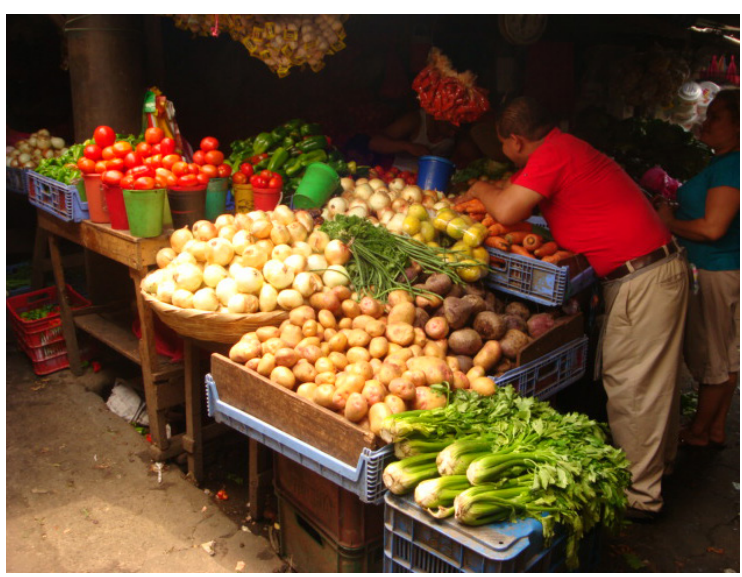

Foto de tramo simple de comerciantes fijos, con estructuras sencillas, complementado de canastas y mesas. Foto realiza en 2014 en trabajo de campo. 
Importante esta señalización, de que no son vistos como agentes económicos, lo que implica una categoría, por debajo de los comerciantes que si lo son. No son vistos como los que están pagando impuestos a COMMEMA, sin embargo son a los que se les atribuye la mayoría de las problemáticas. Son la mayoría incluso en algunos sectores del mercado, en donde la composición general es de comerciantes ambulantes.

Posiblemente es el colectivo que mayor representatividad tiene en los mercados, puesto que se les observa desde los que estan a la par de los buses ofreciendo agua helada, con características morfológicas de maltrato físico y exposición al sol, provocando lesiones y maltrato a su cuerpo. Este tipo de características se logra observar en casi todos los comerciantes ambulantes, que al no tener un tramo con estructura firme, vuelve como tramo todo el mercado o parte de él.

De forma que su vida cotidiana está compuesta en esencia por lo que sus actividades de movilizarse por todos los espacios logra generar ingresos a la familia. En todo caso es una estructura familiar dirigida a ser agente activos de trabajo, tratando de generar un ingreso que permite la supervivencia familiar.

Su condición de precariedad representa una situación de contrastes de cómo se distingue cada comerciante, a partir de un mecanismo de jerarquización, entre los comerciantes fijos y comerciante ambulantes. La población que llega como cliente, considera que existen lugares más peligrosos que otros, como más sanos que otros. En su efecto es una carga sobre la identidad de los comerciantes ambulantes y el espacio donde se encuentren cuando se hace referencia a la peligrosidad.

Julio César Gadea, contador, infiere que, "hay dos tipo de vendedores ambulantes el que se gana la vida honradamente y el que anda vendiendo de esa forma $y$ también roba o hace daño, eso era típico andaban unos cuantos aparentando vender y cuando te descuidas te robaban" (J. C. G. 10/05/14)

Los comerciantes ambulantes son un grupo social que se dinamiza en este espacio. El contexto de mercado se vuelve el lugar dentro del gran lugar, osea, que la ciudad se convierte en ese espacio donde no encuentran lugar para estar y sobrevivir. El Mercado Oriental es el lugar dentro de la ciudad, responde a una lógica de refugio paralelo a la importancia como espacio de comercio considerado por los comerciantes ambulantes. Resulta que ese espacio donde venden, también es el lugar donde se refugian de los choques culturales de la sociedad y sobre todo es su espacio de sobrevivencia social, cultural y necesidades socioeconómicas.

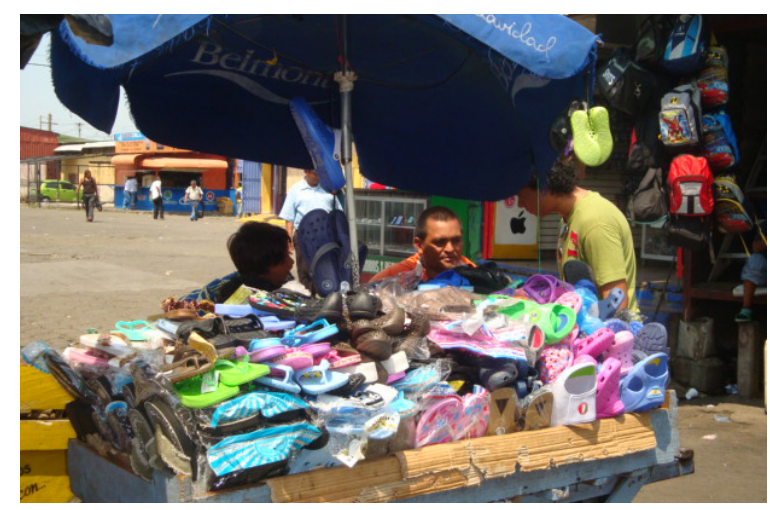

Foto de comerciantes eventuales, vendiendo en carretones. Foto tomada durante trabajo de campo en 2014.

\section{Identidad colectiva y discurso público sobre los comerciantes}

Existen reflejos de la identidad del comerciante a lo interno y externo pero la mirada externa tiene efectos sobre la otra, es decir, que la percepción de la sociedad sobre todos los comerciantes del Mercado Oriental, repercute sobre las relaciones internas de los comerciantes fijos y ambulantes-eventuales.

La dinámica de interacción y las identidades colectivas e individuales que se desarrollan en el mercado lo vuelve un espacio que agrupa concepciones diferenciadas de interpretar a los comerciantes como sujetos activos y con gran riqueza cultural dentro de la ciudad.

Pero la identidad se ve friccionada por los comerciantes precisamente por el discurso de "afuera", de manera que aunque comparten riqueza cultural, están configuraciones socioculturales dentro del mismo espacio.

Los elementos de conflictividad entre los mismos comerciantes se expresan por ejemplo cuando los comerciantes fijos consideran no ser "como los ambulantes que son los ladrones, y cubren las muchas fechorías", y los ambulantes dicen no ser "arrogantes y ladrones de espacio", así se manifiesta una característica de resistencia entre estos dos sujetos, y que los dirige a identificarse con un grupo determinado y difereniarse de otro. 


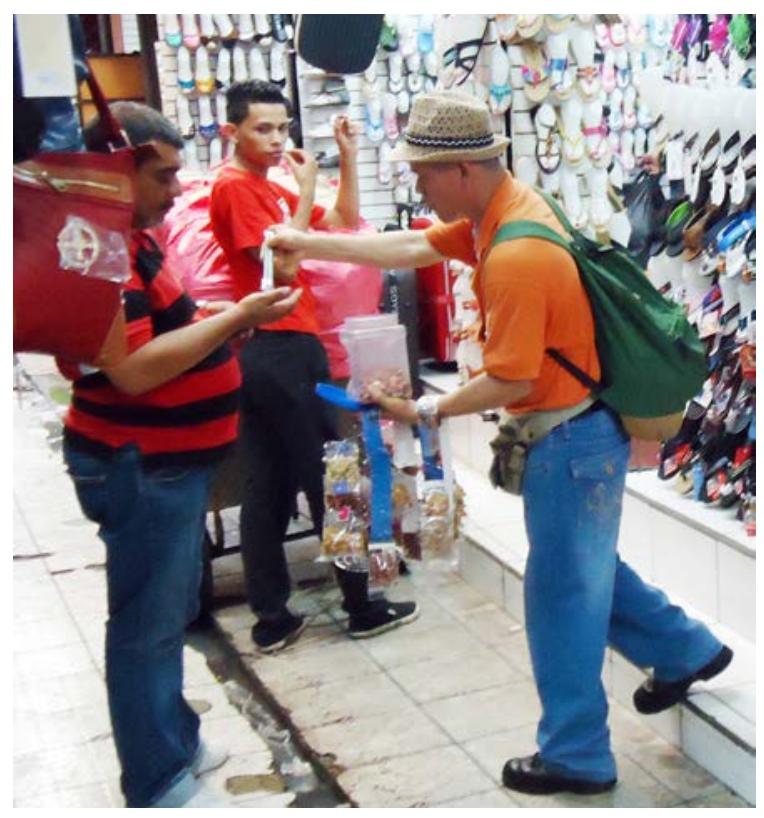

Foto de comerciante ambulante, a este grupo pertenecen los que venden agua helada, golosinas y otros productos en menudeo. Foto realizada durante trabajo de campo en 2013.

Las diferencias entre comerciantes se plasman en niveles subjetivos como objetivos, es decir desde su origen étnico, procedencia social, e incluso los niveles adquisitivos. Es decir responde a la imagen del otro comerciante como "al que me diferencio y no me quiero parecer", esto tiene su implicancia e incluso es relativa para construir una identidad individual.

La identidad individual es necesaria dentro del mercado para que de lugar a la identidad colectiva. Los comerciantes del Mercado Oriental presentan elementos semejantes en terminos generales que construyen una identificación colectiva.

Para ello se mencionan expresiones lingüistícas, como cultura material y relación de espacio. La estrategia para atraer clientes, cantando sus productos es una caracteristicas en común. Los vínculos familiares y por afinidad es otro elemento de identificación colectiva dentro del mercado Oriental.

La identidad colectiva se refleja en: identificación de la jerarquía interna de cada tramo o espacio de venta a través de los delantales. Puesto que el uso del delantal y estar sentado en el tramo o frente al tramo vendiendo $y$ recibiendo dinero ejerce un poder y control sobre el puesto de venta.
La identidad colectiva se percibe a través de la percepción social negativa que genera estigma y exclusión hacia los comerciantes producto del discurso público. Los comerciantes en general del Mercado Oriental comparten la imagen que brindan los medios de comunicación sobre ellos.

La identidad colectiva también se refleja en como el espacio se vuelve un lugar antropológico de construcción de identidad. El mismo es compartido por los comerciantes fijos y ambulantes-eventuales. Aunque cada comerciante da un uso diferente al espacio, las 52 hectáreas significan el Mercado Oriental y ese espacio urbano se resuelve como el espacio de los comerciantes: sean ambulantes-eventuales y fijos.

La identidad colectiva tiene su origen precisamente en las identidades individuales de los grupos de comerciantes. Pues existen identidades individuales que se generan en lo tradicional, comerciantes con orígenes rurales, comerciantes que provienen de las periferias y contextos de hacinamientos urbanos.

Estas realidades entran en contraste de forma que ni una de las dos mantiene una percepción similar del mundo aunque comparten el mismo espacio físico del Mercado Oriental.

\section{Incidencia del discurso público y estigma social en las relaciones entre los comerciantes}

El discurso público creado por los medios masivos, y por la población externa al mercado ha reflejado por años antecedentes de discriminación ante los comerciantes de mercados populares. Basta con revisar las fuentes informativas de periódicos, para dar respuesta a esta aseveración. Los espacios de mercados populares se vuelven la contraparte y resistencia al capitalismo que intenta formalizar los mercados en plazas cerradas con aire acondicionado $\mathrm{y}$ con precios establecidos.

Los mercados populares se vuelven ese lugar de connotación cultural, de peculiaridad social e histórica en donde los comerciantes y sus clientes facilitan el regateo sin formalidad empresarial y capitalista. Y esta es la razón por la que el discurso del poder capital intenta desprender el significado cultural de los mercados y establecer la idea de atrazado o bien espacios de problemáticas sociales. 
Los mercados populares son herencia ancestral, por tanto los comerciantes tiene una esencia en su identidad que los hace relevantes para la sociedad. Pero los discursos difundidos a través de los medios de comunicación generan una imagen de riesgo de los comerciantes, y esto lleva a que las personas intenten ir lo menos posible a los mercados populares. Y se percibe claramente que los comerciantes que no son responsables, y que por lo general son considerados "peligrosos" son esencialmente los que no pagan impuestos a COMMEMA, los que venden de forma ambulante y/o eventual, puesto que son un grupo de contraste con los demás a lo interno del mercado.

El antecedente próximo a este fenómeno se encuentra para los años 90'en el gobierno de doña Violeta Barrios de Chamorro. En esta etapa según las notas periodísticas y los informes estadísticos la violencia de pandillas tuvo un fuerte auge (Rodgers, 2004). Y los mercados se convirtieron en centros importantes de violencia y delincuencia de pandillas. El período neoliberal que atrevesó Nicaragua, bastó para que la sociedad creara un discurso de discriminación sobre los comerciantes sostenido hasta la actualidad.

Por consiguiente los problemas sociales internos se traspolan a nivel externo y comienza el discurso público a configurar la identidad colectiva de forma negativa. La diferencia interna entre los comerciantes tiene distintas vertientes entre ellas: origen y clase social, procedencia y origen local, características étnicas y estilo de vida. Y los antecedentes históricos de Nicaragua sobre delincuencia.

Por tanto los problemas familiares, sociales y educativos que pueden pasar los comerciantes y sobre todo los ambulantes son interpretados como problema social y discriminación. El discurso que se maneja es que los que no estudian, son delincuentes. Aunque las autoridades locales en la actualidad hagan esfuerzos por lograr desarrollar a los comerciantes en el ámbito social, educativo y familiar, el discurso está creado. Lo que resta es resistirse ante esta posición y es por ello que a lo interno los comerciantes crean conflictos porque ninguno quiere cargar con la discriminación creada por los medios masivos y el discurso público.

Desde afuera se percibe una sola identidad colectiva, pero si se observa mejor al comerciante, se notan características distintas entre el mismo grupo social. Desde adentro se comprende que existen identidades conformadas en grupos bien segmentados unos de los otros, y que la mirada desde afuera repercute en las demarcaciones de choques y conflictos entre los mismos comerciantes, lo mismo infiere que producto de la lucha de identidades que surgen cuando se generaliza la identidad y caracteristicas del comerciante, es que conciben los orígenes de problemas sociales demarcados como la falta de educación, salud e higiene, puesto que marginan a lo interno del mismo mercado.

Augusto Rivera da su testimonio indicando que "casi un $40 \%$ de los comerciantes ambulantes estos tienen las mayores necesidades vistas en el mercado, sus hijos viven en malas condiciones y no estudian en su mayoría, generalmente padecen de desnutrición, vienen de familias pobres, en su mayoría están habitando el mercado como el lugar de dormir, pero esto creo yo se debe a que lamentablemente en su mayoría yo diría un $90 \%$ de las vendedoras son madres solteras y jóvenes vulnerables." En cambio los comerciantes fijos tienen mayores oportunidades. Los comerciantes fijos tienen a sus hijos en educación básica y superior. Tienen mayor nivel adquisitivo.

Los comerciantes fijos tienen otros modos de vidas. Otra procedencia social y mantienen a los hijos en educación y alternativas de recreación fuera del mercado hasta cuando sea necesario. Lo que no ocurre con los comerciantes ambulantes-eventuales que no logran dar esas oportunidades a sus hijos, porque los mismos andan en ese espacio trabajando para generar medios para sobrevivir.

Lisseth Bermudez agrega que "esto es difícil, porque en verdad son un montón de niñas las que salen embarazadas ahora, en malas condiciones de salud, ellas no prestan buena lactancia y se desnutren así qué futuro le puede esperar a la pobre criatura. Y lo peor no salen del mercado, porque nadie les da trabajo porque son de cierta forma discriminadas"

"Yo pienso que los padres tienen que buscar cómo ayudarle a sus hijos y mandarlos aunque sea un ratito a la escuela pero eso tiempo el cual ellos no están dispuesto a perder" (Bermudez. 2014)

Ante una situación como esta, se generan conflictos y problemas internos. Estas problemáticas son convertidas en discursos que mantienen una marginalidad 


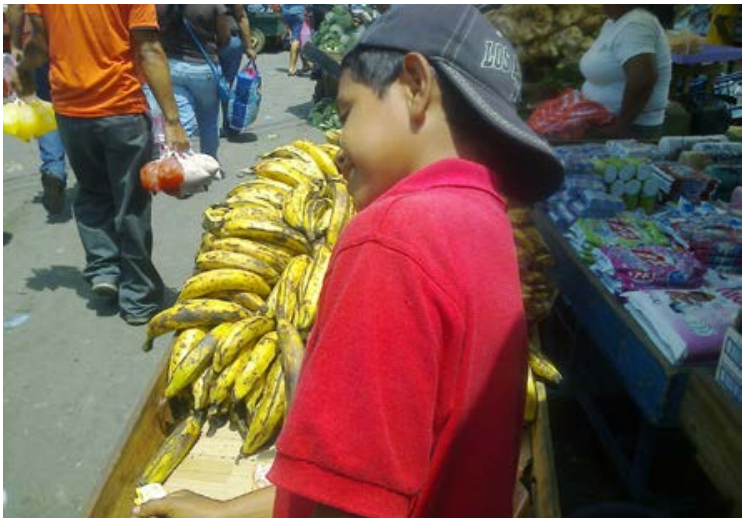

Foto de un niño comerciante ambulante-eventual, esto refleja el que recibe y reproduce las diferencias y estigmas creados por el discurso público. Foto realizada durante trabajo de campo en 2015.

para los comerciantes ambulantes-eventuales. Y las agrupaciones de comerciantes, inclusos los grupos delictivos son generadas por el discurso y las necesidades individuales. Los comerciantes ambulantes-eventuales se refugian entre ellos por características comunes.

Dicho de otra manera, los estigma que la población hace desde afuera incide directamente en las relaciones entre los comerciantes a lo interno, provocando un rechazo y estigma entre los mismos comerciantes de características diferentes. El estigma social provocado desde afuera se percibe como una identidad colectiva de ver al comerciante, reproduciéndose este percepción entre los comerciantes que no quieren ser visto de esa manera y atribuyen la "culpa" al otro comerciante más vulnerable.

Bajo esta lógica de los orígenes de los conflictos por distinción de identidades, menciona Amartya Sen, que "Vivir en la pobreza puede ser triste, pero "ofender o causar dolor a la sociedad" creando "problemas a quienes no son pobres", es, al parecer, la verdadera tragedia." (Sen, 1992, pág. 1)

El autor infiere que los orígenes y diferencias de ser rico o pobre lo dispone, quien posee un poder hegemónico sobre quien no lo dispone. En este sentido la influencia de los medios de información es esencial, puesto que contribuye a legitimar esta desigualdad partiendo de niveles económicos o bien estatus que otorga un ente superior.

En este caso las identidades están configuradas a partir de la realidad concreta de cada momento histórico. Mientras en un momento el mercado era popular tra- dicional (1930-1970 aprox.) en estos momentos es una ambigüedad de lo tradicional y moderno. Lo mismo provoca distancia en la subjetividad de los comerciantes a lo interno del Mercado Oriental.

Ejemplos claros de discriminación son como las personas se refieren a los comerciantes del Mercado Oriental: se trata de discursos que alimentan la idea de ver al comerciante como el ser vulgar. La población para hacer mofa, o chiste o bullyng a algún conocido o amigo que habla mucho y con grosería, le dice "tenés las tapas de una mercadera" (Silvia Pérez, 04, 05, 2015), esto contribuye al discurso y la imagen estigmatizada del comerciante. Esto sin duda es parte del discurso creado sobre el comerciante y su identidad, y por consiguiente los comerciantes reflejan choques de identidad a lo interno.

Sin embargo aunque el discurso genera choques y conflictos, a los interno los comerciantes (fijos y ambulantes-eventuales) se relacionan entre sí, generando una relación de contradicciones. Puesto que existen diferencias entre los comerciantes, pero a la vez estos comparten un mismo espacio que significa su lugar, su espacio de sobrevivencia y esto los hace relacionarse entre ellos. Ya que entre ellos se prestan bienes y servicios.

La cultura de los comerciantes a partir de las actividades que ejercen, les identifica pero además estas identidades están presentes en los procesos de relaciones sociales a lo interno del mercado. Las relaciones sociales pueden dirigirse en dos vías: conflictivas y de pertenencia social, las dos tienen que ver directamente con la identidad construida tanto internamente como construcción estigmatizada desde afuera.

Las identidades serán para los comerciantes una forma de diferenciarse sobre quién será el marginado y quién no lo será. Existe una resistencia de un grupo social con otro a lo interno del mercado, de manera que los choques resultan como un producto de la información que se maneja y manipula desde "afuera" provocando orientación entre los comerciantes a marginar y el otro que rechaza sentirse estigmatizado, aunque en términos reales, es un ser estigmatizado ante el público que no es comerciante. 


\section{Discusión de resultados}

Las relaciones sociales dan lugar que las identidades se establezcan en un espacio, pero también permiten el desarrollo de una dinámica de vivencias y aprendizajes de los individuos en el tiempo. En los mercado se experimenta esta relación: tiempo, espacio y caracteristicas culturales de los individuos; esto por supuesto da lugar a una identidad colectiva que surge de las identidades individuales y grupales. (Rota, 2009)

Los comerciantes fijos y ambulantes del Mercado Oriental construyen una realidad sociocultural a partir de su cultura e identidad que han aprehendido, construido y reproducido en el tiempo. El discurso público y la influencia de los medios de comunicación masivo, visto desde el enfoque antropológico, en realidad también contribuyen a la exclusión social y discriminación dentro del mercado como fuera del mismo. (Maldonado \& Hernández , 2010, pág. 233)

El mercado con respecto a los "otros" de la sociedad misma, pero dentro del mismo la lógica indica que entre ellos lo que existe es una filiación restringida de valores socioculturales que los distintos grupos conformados expresan y esto responde a necesidades e interés de los individuos de afiliarse y restringirse de los "otros" grupos. (Krotz, 1994)

Las realidades concretas de quienes conforman los sub grupos en una sociedad van generando otros sistemas a lo interno del grupo, como ejemplo los comerciantes del Mercado Oriental configuran su cultura a partir de realidades que identifican a unos y separan a otros comerciantes como los ambulantes-eventual de los fijos, ambos segmentos tienen realidades distintas. (Krotz, 1994)

De manera que esa condición está ligada a las formas cómo establecen estrategias de subsistencia dentro de un espacio traducido a formas estratégicas de relaciones sociales (Pfefferkorn, 2007) donde tratan de buscar maneras de mantener su supervivencia con aliados. Como se percibió en los resultados de la investigación el comerciante tiene choques de identidades entre ellos como respuesta a lo que el sistema social hegemónico provoca (Sen, 1992).

El sistema social genera la condición compleja de como se van a relacionar los comerciantes a lo interno, teniendo conocimiento que tienen identidades particulares (Godelier, 2010), pero además se afilian a identidades colectivas (Maldonado \& Hernández, 2010) no como una falta de recursos, sino también como una condición para responder al discurso que provocan los medios de información. De acuerdo a lo que plantea Amartya Sen (1992) para comprender la pobreza hay que abordar la desigualdad. Además los antecedentes delictivos en el tiempo y el discurso genera discriminación y estratificación social entre los individuos a los interno y por supuesto a lo externo.

\section{Conclusiones}

Los comerciantes conforman un conglomerado más amplio y complejo de relaciones sociales, de configuración social, de redes de intercambios reinterpretadas a través del tiempo y estructuras sociales. El comerciante es un ser social y económico que configura su realidad, redefiniéndola como estrategias de supervivencia para resistir los cambios de los sistemas socioeconómicos del país. Comercializa bienes y servicios a un sector de la sociedad, pero además negocia su identidad con el resto de los sujetos que interactuan con él, para convertirse en actor social que resiste choques desde afuera del mercado.

Además se interpretó que desde afuera se percibe una sola identidad colectiva, observar al comerciante como un solo grupo social sin características distintas entre ellos. Pero la realidad es diferente: existen tantas indentidades individuales como comerciantes existen, de forma que el mercado es un espacio heterógeneo de identidades que se relacionan entre sí, logrando pertenenpertenencia y rechazo entre ellos. Lo que infiere que producto de la lucha de identidades que surgen cuando se generaliza la identidad y características del comerciante, es que conciben los orígenes de problemas sociales explicítos en el Mercado.

Los medios de comunicación en gran parte han provocado una imagen estigmatizada del comerciante, lo que ha tenido repercusiones a lo interno. Es decir que mientras la sociedad estigmatiza al comerciante del Mercado Oriental en general, éste a lo interno reproducirá de forma conciente o inconciente el estigma al comerciante más vulnerable para encontrar una respuesta al estigma que se sufre desde afuera. Por último se deduce que para interpretar al comerciante del mercado Oriental se debe visualizar dos formas de concebirlo: la mirada desde adentro y la miradas desde afuera del mercado, para evitar prejucios y estigma entre los mismos comerciantes al interno del mercado. 
Los mercados en la actualidad no están necesariamente segmentados en tradicional y moderno o mercados de función domésticas o macroeconómicas, ni tampoco están fuera de la ciudad necesariamente como afirman Molina \& Valenzuela (2006). Los hallazgos indican que el contexto de investigación converge entre lo moderno y tradicional y que además se encuentra dentro de la ciudad como centro de fluidas relaciones como también resctricciones sociales.

\section{Bibliografía}

Betancourt Echeverry, D. (2004). Memoria individual, memoria colectiva y memoria histórica: lo secreto y lo escondido. CLACSO-Colombia, 125-134.

Bolívar, T., \& Erazo Espinosa, J. (2013). Los lugares del hábitat y la inclusión. Quito, Ecuador: FLACSO.

Chomsky, N., \& Ramonet, I. (2002). Cómo nos venden la moto. Barcelona: Icaria Editorial.

El Nuevo Diario. (23 de Marzo de 2010). Mercado Oriental, monstruo que se traga a Managua. Ningún gobierno lo doma, y crece y crece... , pág. http://www.elnuevodiario.com.ni/busqueda/?q=Mercado+Oriental.

El Nuevo Diario. (10 de Diciembre de 2012). El Mercado Oriental, vástago del Terremoto de 1972. EL Nuevo Diario, págs.http://www.elnuevodiario.com.ni/terremoto1972/271670-mercado-oriental-vastago-terremoto-1972/.

El Nuevo Diario . (4 de Septiembre de 2013). Inicia reor denamiento en el Mercado Oriental . Plan recomendado por Defensa Civil e instituciones de socorro, págs. http://www.elnuevodiario.com.ni/managua/295930-inicia-reordenamiento-mercado-oriental/.

El Nuevo Diario. (3 de Diciembre de 2014). Incendio en el mercado Oriental. END, págs. http://www.elnuevodiario. com.ni/nacionales/336370-incendio-mercado-oriental/.

El Nuevo Diario. (8 de Enero de 2015). El Oriental un mercado voraz . END, págs. http://www.elnuevodiario.com.ni/ managua/340371-oriental-mercado-voraz/.

END. (08 de Agosto de 2008). Nacimiento y gigantesca expansión. Obtenido de El Nuevo Diario : http://www.elnuevodiario.com.ni/nacionales/23107-nacimiento-gigantesca-expansion/

Garza, D. G. (2011). Una etnografía económica de los tacos callejeros en México. El caso de Monterrey. Estudios Sociales.
Redalyc, 32-63.

Godelier, M. (2010). Comunidad, sociedad, cultura. Tres claves para comprender las identidades en conflicto. Cuadernos de Antropología Social No 32., 13-29.

Hammer, M., \& Atkinson, P. (1995). Etnografía Métodos de Investigación. Barcelona: Paidós.

Krotz, E. (1994). Cinco ideas falsas sobre "la cultura" . Revista de la Universidad Autonoma de Yucatan, 31-36.

Maerk, J. (2010). Desde acá - Tepito, barrio en la Ciudad de México. Redalyc, 231-542.

Maldonado, A. M., \& Hernández, A. (2010). El proceso de construcción de la identidad colectiva. Redalyc, 230-251.

Miguélez, M. M. (12 de Diciembre de 2005). El Método Etnográfico de Investigación. Obtenido de http://prof.usb.ve/ miguelm/metodoetnografico.html

Molina, J. L., \& Valenzuela, H. (2006). Invitación a la Antropología Económica. España: Bellatera.

Moreno, I. (1997). Trabajo, ideologías sobre el trabajo y culturas del trabajo. Revista Andaluza de Relaciones Laborales.

Narváez, N. S. (2014). Comerciantes, corredores y marchantes: el Mercado Oriental de Managua como espacio de interacción social. Humanismo y Cambio Social. $\mathrm{N}^{\circ}$ 4, 92-105.

Pfefferkorn, R. (2007). Las Relaciones Sociales de Sexo. Revista Social, 55 .

Ramírez, M. J. (2008). Aproximación teórica de la exclusión social: complejidad e imprecisión del término. Consecuencias para el ámbito educativo. Estudios Pedagogicos, 173-181.

Rodgers, D. (2004). Pandillas: de la violencia social a la violencia económica. Envío, Número 272.

Rota, J. A. (2009). El concepto de Cultura en Antropología Contemporánea. Consello da Cultura Galela, 10.

Sen, A. (1992). Sobre conceptos y medidas de pobreza. Comercio Exterior, 1-13.

Solano, G. M. (1994). Etnografía de plazas de mercados de Bogotá. Revista Aportes, 2-58.

Towell, J. L., \& Attolini Lecón, A. (2009). Caminos y mercados en México. México: Universidad Nacional Autonóma de México. 